\title{
Development Inter-budgetary Fiscal Relations on the Basis of the Model of Subnational Budgets
}

\author{
Gaizatullin R. R. ${ }^{1}$, Zapparova Zulfira Nurtdinovna ${ }^{1}$, Vafin I. N. ${ }^{1}$ \& Pratchenko O. V. ${ }^{1}$ \\ ${ }^{1}$ Kazan (Volga region) Federal University, 18, Kremlevskaya st., Russian Federation \\ Correspondence: Gaizatullin R. R., Kazan (Volga region) Federal University, 420008, 18, Kremlevskaya st., \\ Russian Federation. E-mail: lenar_s@mail.ru
}

Received: August 22, 2014 Accepted: September 5, 2014 Online Published: November 27, 2014

doi:10.5539/ass.v10n24p165

URL: http://dx.doi.org/10.5539/ass.v10n24p165

\begin{abstract}
The aim of the work is to develop the tools of mechanism of functioning of inter-budgetary fiscal relations on the basis of the model of subnational budgets. In accordance with the aim of the research, the algorithm of analysis of efficiency of implementation of the budgetary development program is offered, multiple-choice regional model of budgetary resources management is developed in the article. In spite of the great number of works devoted to the problems of regional regulation of inter-budgetary and social-economic processes, a lot of questions of their practical implementation, including questions of optimization of expenditures of budgetary funds, are still insufficiently developed. It determined the purpose and objectives of the study. In work the model of concentration of budgetary resources in order to increase the number of subjects of taxation is implemented at the expense of increase of number of employees of manufacturing sphere with the current level of wages and at the expense of investment support of development of small and medium-size business.
\end{abstract}

Keywords: inter-budgetary fiscal relations, budgetary federalism, subnational budget, regional governance, budget development programs

\section{Introduction}

World economic crisis of 2008 caused aggravation of structural imbalances in the Russian economy, including the contradictions in the system of public finances characterized by the growing level of centralization of income at the federal level. The use-together with inter-budgetary fiscal transfers, the volume of which varies in accordance with the accepted methodical procedure in the system of fiscal regulation-of special and non-formalized forms of financial support of subjects of the Russian Federation leads to limited results of measures to reduce the existing differences in the fiscal capacity of the regions through inter-budgetary fiscal transfers and the simultaneous reduction of regional incentives for the development of their own taxation base. The overall effectiveness of federal transfers which is determined as a specific amount of resources aimed at reducing fiscal imbalances tends to decrease in the specified period.

The analysis of regional development of inter0budgetary fiscal relations is presented in the works of Korchagin U., Osborne D., Gaebler T., Paugam A., Pedraja-Chaparro F, Salinas-Jiménez J., Suárez-Pandiello J., Posner P., Qian Y., Weingast B., Goglio A., Sancton A., Searle B. and others.

However, in spite of the great number of works devoted to the problems of regional regulation of inter-budgetary and social-economic processes, a lot of questions of their practical implementation, including questions of optimization of expenditures of budgetary funds, are still insufficiently developed. It determined the purpose and objectives of the study.

\section{Methodology}

Conceptions and hypotheses, well-founded and presented in modern economic literature, which are devoted to the principles of regional governance, socio-economic forecasting, theory of systems, as well as works that reveal the methodological basis of the research of fiscal processes at the micro-, macro-levels, management of resources' provision of regions, patterns of functioning of budgetary system and implementation of the budget process, became the theoretical and methodical basis of the research (Osborne \& Gaebler, 1992; Paugam, 1999; Pedraja-Chaparro, Salinas-Jiménez, \& Suárez-Pandiello, 2006; Posner, 1998; Qian \& Weingast, 1997; Goglio, 2004; Sancton, 2002; Searle, 2002). 


\section{Results}

Algorithm of the analysis of efficiency of implementation of budgetary development programs is the result of the research study; it includes the following stages: analysis of deviation of values of programs indicators; identification of interconnections with other programs; calculation of deviations; calculation of the volume of reduction of funding; calculation of the total amount of reduction of volume of finance for the full list of programs; at that the analysis of the implementation of the accepted obligations is made by authorities of Treasury on the basis of comparison of actual volumes of implementation of the accepted obligations and their planned values. In the process of the study the tools of functioning of inter-budgetary fiscal relations on the basis of the model of subnational budgets, including regulatory inter-budgetary redistribution of income sources, the formation of the investment fund with revenues from the issue and placement of government bonds in the amount and in terms in accordance with the objectives of the development and strengthening of sub-national budgets, are developed. It allowed establishing the multivariate regional model of budgetary resources management; this model includes elements of the model focused on the increasing number of subjects of taxation; the model focused on development of labor productivity of workers; model focused on maintenance of budget surplus.

\section{Discussion}

Recognition and monitoring of accepted obligations is the necessary condition of increase of effectiveness of using the budgetary funds. If fixed fiscal revenues in the municipal budget are insufficient to solve the problems of local authorities, then the amount of subsidies and grants allocated to solve the local problems, according to the rules provided by the Budget Code of the Russian Federation, is set (Budget Code of the Russian Federation; Budget Strategy of the Russian Federation for the period until 2023). At the moment there are no formal mechanisms to regulate the procedures of execution of local budgets concerning allocated powers assigned to the municipalities (Main results and directions of fiscal policy for 2012 and to the period up to 2014). In reality with presence of the procedure of revocation of authorities established by regional laws-in case of their non-execution-after the adoption of the local budget by the representative body of the local authority to put into practice this legal norm and to adjust the volume of transmitted budgetary funds is extremely difficult. The authors of the work offer the algorithm of the analysis of effectiveness of implementation of obligations and mechanism of regulation of budgetary funds for their performance on the example of the complex of budget-financed programs (Figure 1).

Analysis of the implementation of accepted obligations is made by the Treasury authorities by comparing the actual amount of implementation of accepted obligations and their planned values. Calculation is made within the frames of the proposed method by the following formulas:

$$
\begin{aligned}
& \Delta \mathrm{V}_{\mathrm{i}}= \mathrm{V}^{\mathrm{n}}{ }_{\mathrm{i}}-\mathrm{Vi} \text { fact } \\
& \mathrm{C}_{\mathrm{i}}{ }^{\mathrm{n}}=\sum \mathrm{n}_{\mathrm{i}} \times \Delta \mathrm{V}_{\mathrm{i}} \\
& \mathrm{C}=\sum \mathrm{C}_{\mathrm{i}}{ }^{\mathrm{n}}
\end{aligned}
$$

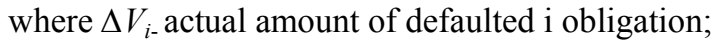

$V_{i}^{\text {hakm }}$ : actual amount of performed i obligation in natural indicators;

$V_{i}^{H}$ : normatively established amount of $i$ obligation in natural indicators;

$C_{i}{ }^{n}$ : estimated amount of i defaulted obligation;

$C$ : estimated amount of all defaulted obligations of the account period.

Replenishment of shortfall of regional and municipal budgets is executed by redistribution of revenues between the territories. In connection with this, we offer to optimize the shared distribution of revenues from the main regulating revenue sources: VAT, income tax, individual income tax and excise taxes-between the federal and regional budgets, in case of which the strengthening of the financial autonomy of the regions can be achieved.

Creation of budgetary investment fund on the federal level, the means of which are distributed between the subjects of the Russian Federation for purposes of budgetary support of their economic development, can become one of possible solutions of this problem. Investment fund can be formed by means of sources of the federal budget; funds raised by Russian Government by issuing and allocation of public investment securities (bonds) of long-term nature. The Government of the Russian Federation appropriates borrowed-from the placement of investment bonds-resources to subjects of the Federation for realization of their investment strategy. Allocation of resources shall be in accordance with the territorial quota (Figure 2). 


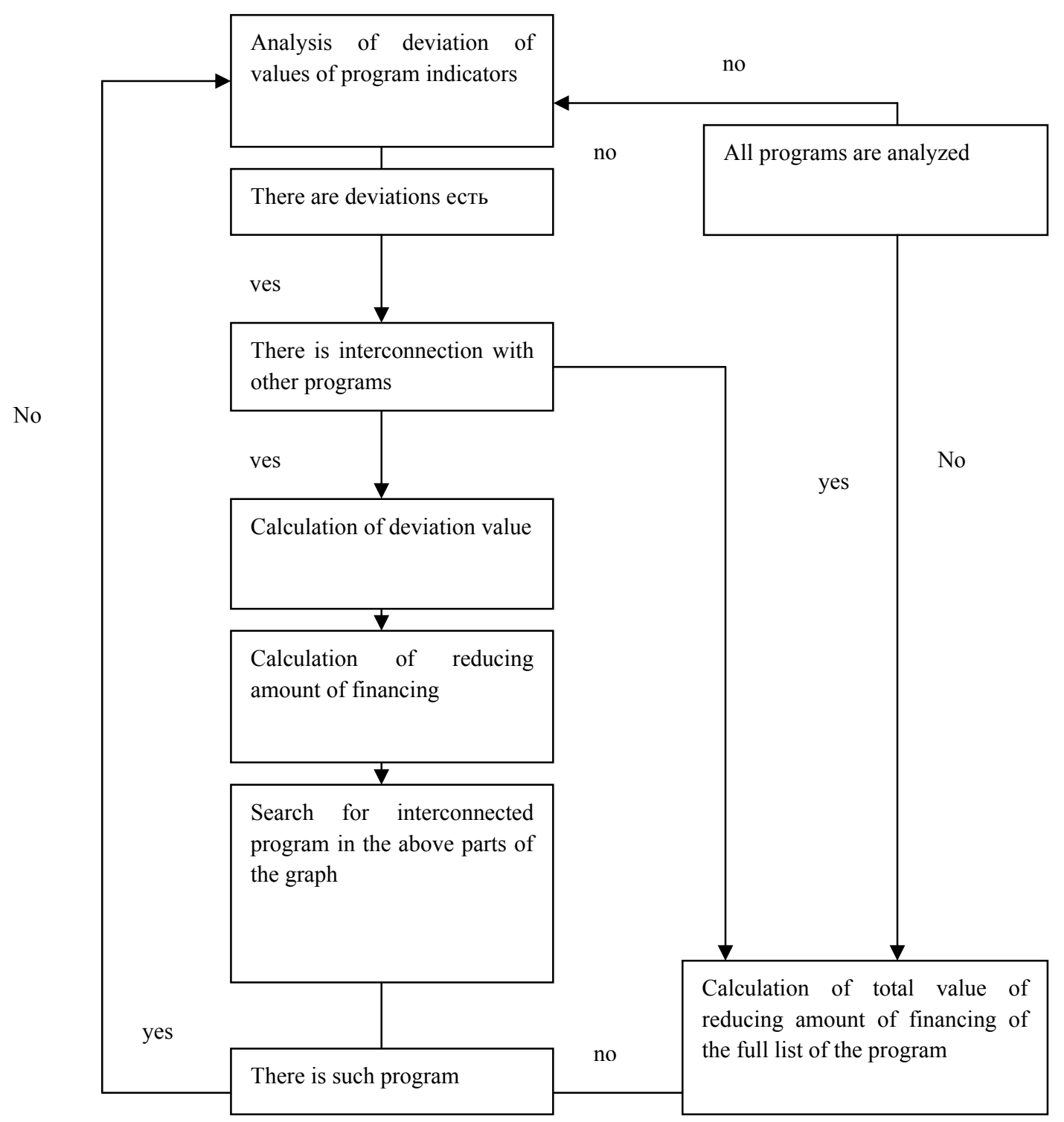

Figure 1. Algorithm of the analysis of effectiveness of implementation of programs of budget development

Due to the fact that investment bonds will partake of public securities, the rate of return on them should be low. Based on the experience of placement of government bonds, the estimated return of federal bonds of long-term nature should be at the level of $1 / 2$ of the refinancing rate. With the account of the margin which covers the costs of the Government of the Russian Federation and the subjects of the Federation for implementation of this project, the investment resources to subjects of the Russian Federation shall be provided at the rate of 1/2 of the refinancing rate $+1 \%$ per annum. Investment fund established by the subject of the Russian Federation should be preferably used not for public financing of investment projects, but for compensation of part of the interest rate on loans given to business entities by commercial banks. Currently such form of budget support of investment activity is the most effective one. Declared within the frames of the reform of inter-budgetary fiscal relations the liability management method should be replaced by the method of management of budget revenues. Thus, the subjects of budget planning will function like effectively working "profit centers" of vertically integrated corporations (Корчагин, 2013). Inefficient management of budget revenues, which can be estimated according to the implementation of planned figures with regard to growth of budget revenues approved by the Government of the Russian Federation, will indicate ineffective work of local authorities.

Implementation of the task of efficient management of budgetary resources is possible within the frames of three regional models of management of budgetary resources: the model of concentration of budgetary resources in order to increase the number of subjects of taxation; the model of concentration of budgetary resources in order 
to increase labor productivity of workers; the model of concentration of budgetary resources in order to maintain excess of income over expenditures of the budget.

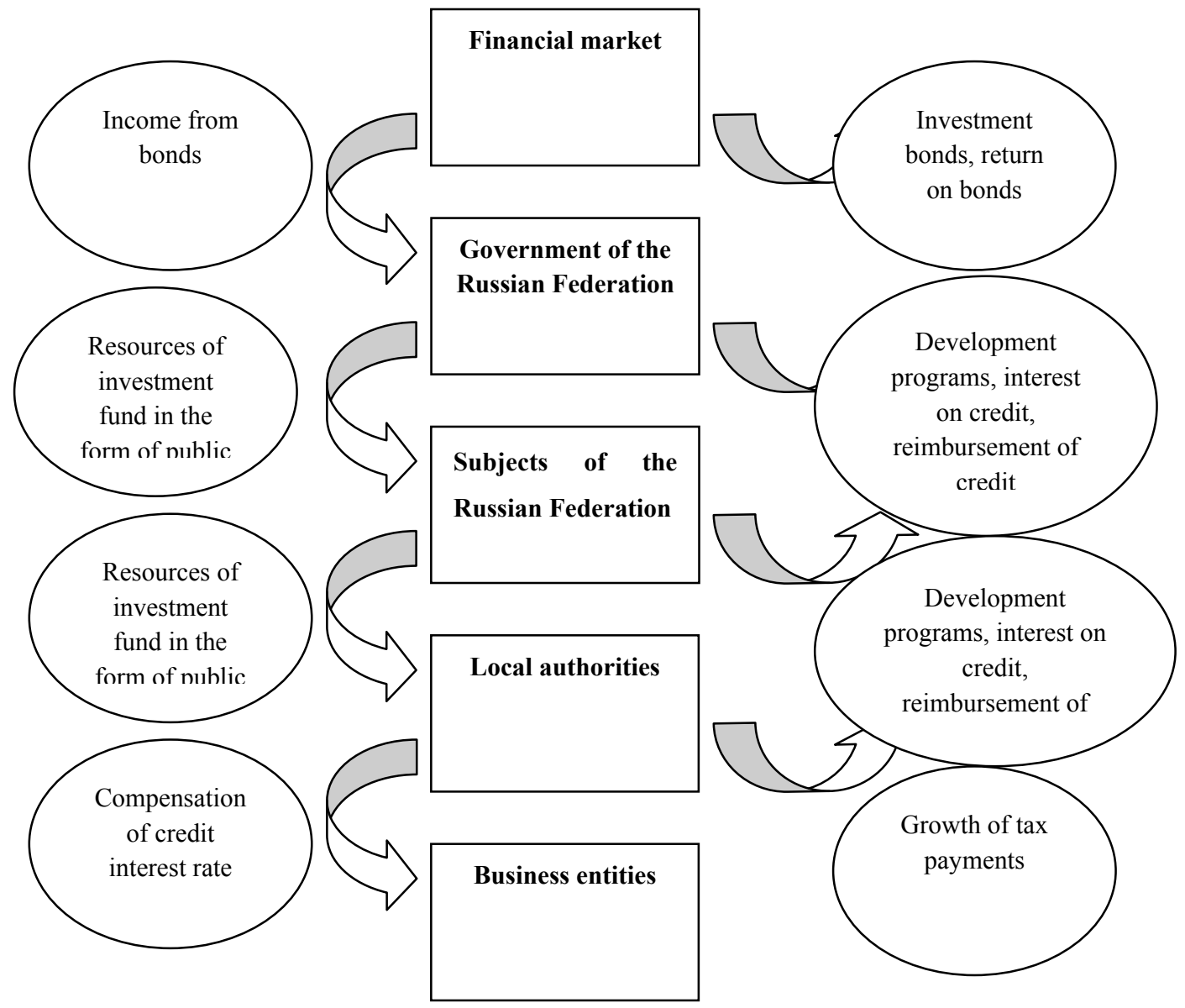

Figure 2. Tools of mechanism of functioning of inter-budgetary fiscal relations within the frames of the model of subnational budgets

The model of concentration of budgetary resources in order to increase the number of subjects of taxation is implemented at the expense of increase of number of employees of manufacturing sphere with the current level of wages and at the expense of investment support of development of small and medium-size business. Increasing number of small and medium-size enterprises will create new workplaces. Providing the conditions for business will contribute to the legalization of "gray" labor market.

The model of concentration of budgetary resources on the increase of wages of existing workers is implemented at the expense of increase of wages with the actual number of workers. Table 1 presents data concerning volumes of expenditures of budgetary funds for social sphere. The model of concentration of budgetary resources for liquidation of budget surplus is focused on predetermined surplus budget planning, and forecast of correlation between social development programs in the process of planning of the expenditure budget in investment resources is presented in Table 1 .

Table 1. Structure of regional expenditure budget (data of Ministry of Finance of the Russian Federation)

\begin{tabular}{lllll}
\hline Structure of expenditure budget & 2009 & \multicolumn{3}{l}{2010} \\
\hline Expenditure budget of programs, in total: & 68741 & $100 \%$ & 75228 & $100 \%$ \\
Education & 28946 & 42.1 & 32847 & 43.6 \\
Health care, physical culture and sport & 19433 & 28.3 & 20696 & 27.5 \\
Culture, art and mass media & 4545 & 6.6 & 4840 & 6.4 \\
Social welfare & 15817 & 23 & 16845 & 22.5 \\
\hline
\end{tabular}




\section{Conclusion}

The analysis allows suggesting that the financing of social development programs will remain on the same level. If during the implementation of programs the budget will be really surplus, it will be possible to form a reserve fund, regulations of use of which should be registered and approved appropriately (Вафин, 2010; Гайзатуллин, 2008).

\section{Regional budget}

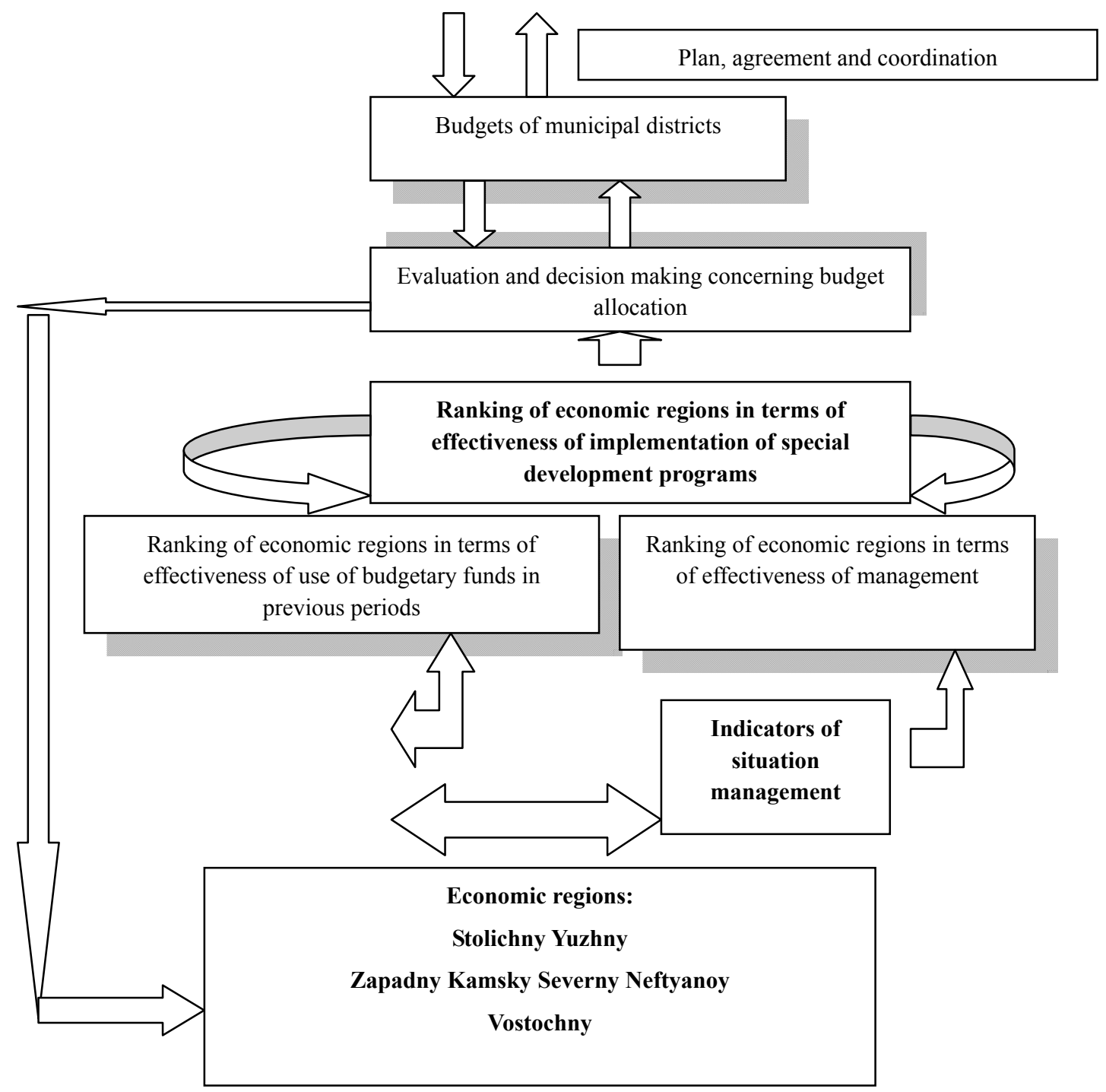

Figure 3. Regional model of budgetary fiscal resources management

The analysis conducted enables us to establish two alternatives for institutional integration forms of bank and industrial capital $(11,15)$ where the leading position belongs to the bank and real economy sectors. If bank is the financial center of the group and administers the structure, then it successfully manages bank assets and equities, and handles financial management of the group, which is customary for the majority of integrate holding structures lacking relevant legal position.

Regional bank strategy must be specific, measurable, achievable, relevant to the purpose, timely. According to these principles we can establish a series of the following steps: developing a mission, strategic development framework, setting goals and creating intervention mechanisms. Regional bank's mission is to promote economy and commonwealth of the region by providing high-quality banking services to enterprises-members of the integrate organization, according to high professional and ethical standards which guarantee bank profit, 
investor's dividends, shareholder's benefit, IHS consolidated profit and fair treatment of bank officials. Then strategic development framework consists in stable competitive edge concept. The regional bank's goals are efficient allocation of resources, fundraising, active and passive banking transactions management, personnel administration, creation of supervisory bodies, bringing the bank duties to notice of the personnel, planning and control; public relations, banking services positioning, promoting new banking product. Implementation arrangements are to establish strategic position, elicit one or several competitive strength sources, build up business concept, and come into contact with the consumer. Creation of development strategy for regional banks in the context of macroeconomic instability makes it possible to work out a bank management system which aims to reduce variability, ambitendency and threshold effect. If implemented, this strategy will provide positive synergetic effect due to integration with real sector companies (16).

As follows from the analysis, we can establish three strategic positions of regional bank as IHS financial center: adapting, formative and conservative (reserving a right to play). According to adaptation policy the bank takes every opportunity to avert certain threats. Formative policy aims to change economic environment, such as offer new banking products and services; develop new competitive win strategies. Conservative policy comprises a number of minimum required actions to keep dominant position on the loan facilities market.

\section{Summary}

Thus, it is possible to generate the revenue side of the budget, without prejudice for development budget. In general, the implementation of these models will allow: for federal authorities-to increase the share of the federal budget allocated for investments into the Russian economy, as well as to get additional income from these funds (in the form of commission and an increase of tax revenues in the federal budget from the development of investment activities); for regional authorities-to attract investment resources on favorable terms, which they could not do before because of the legislative limitations, and also due to the unstable financial situation caused by the current system of formation of revenues and expenditures of regional budgets, and for business entities-to gain access for investment resources of long-term nature of the banking system on favorable terms.

\section{References}

Ajupov, A. A. (2013). The Design and Use of Swap-contracts in the Financial Markets. World Applied Sciences Journal, 27(13), 1-4.

Anisimova, T. Y. (2013). Analysis of standards in energy management. Middle-east Journal of Scientific Research, 13(5), 654-657.

Crivelli, E. (2011). Subnational fiscal behavior under the expectation of federal bailouts. Journal of Economic Policy Reform, 14(1), 41-57. http://dx.doi.org/10.1080/17487870.2011.543760

Fakhrutdinova, E., Kolesnikova, J., Yurieva, O., \& Kamasheva, A. (2013). The commercialization of intangible assets in the information society. World Applied Sciences Journal, 27, 82-86.

Fakhrutdinova, E., Safina, L., Kolesnikova, J., \& Mikhailov, F. (2013). Quality formation of working life of the youth. World Applied Sciences Journal, 27, 87-91.

Garatti, A. (2003). Implications des chocs communs et spécifiques pour le fédéralisme budgétaire Européen. Economie Internationale, 93(1), 89-115.

Glebova, I. S., Khabibrakhmanova, R., \& Yasnitskaya, Y. (2013). The Analysis of the Impact of the Investment Attractiveness Factors of the Region on the Fixed Capital Investments in the Economy of the Republic of Tatarstan. Middle-east Journal of Scientific Research, 17(10), 1498-1502.

Glebova, I. S., Rodnyansky, D., Sadyrtdinov, R., Khabibrakhmanova, R., \& Yasnitskaya Y. (2013). Evaluation of Corporate Social Responsibility of Russian Companies Based on Nonfinancial Reporting. Middle-east Journal of Scientific, 13(Socio-Economic Sciences and Humanities), 143-148.

Guerrero, M. M. (2012). The Reform of art. 135 of the Spanish constitution. Teoria y Realidad Constitucional, 29(1), 131-164.

Kirshin, I. A., \& Gareev, B. R. (2013). Theory of constraints in value based cost management. World Applied Sciences Journal, 27, 102-106.

Melnik, A. N., \& Sadriev, A. R. (n. d.). Problems and prospects of the formation of clusters in the power engineering. World Applied Sciences Journal, 25.

Niu, M. (2013). Fiscal Decentralization in China Revisited. Australian Journal of Public Administration, 72(3), 251-263. 
O'Neal, M. (2014). Invisible and slow: Small business and the "civic-ness" of Russia's regions, 1991-2009. Post-Soviet Affairs, 30(4), 324-340.

Paugam, A. (1999). Reform towards Ad Valorem Property Tax: Fiscal and Nonfi scal Benefi ts in Transition Economies. Paper presented at the International Property Tax Institute's Second Annual Conference. July 1. Krakow, Poland.

Qian, Y., \& Weingast, B. (1997). Federalism as a Commitment to Preserving Market Constrain. Journal of Economic Perspective, 11, 4. http://dx.doi.org/10.1257/jep.11.4.83

Safiullin, L. N., Shaidullin, R. N., Ulesov, D. N., \& Shigabieva, A. M. (2014). Essential features of small and medium business. Life Science Journal 2014, 11(6s), 392-395.

Safiullin, L. N., Shigabieva, A. M., Mazitov, V. M., \& Saipullaev, U. A. (2014). Some methodological foundation of an innovation theory. Life Science Journal, 11(6s), 388-391.

Searle, B. (2002). Federal Fiscal Relations in Australia-2001. Retrieved from http://www.icer.it/docs/wp2002 /searle01-02.pdf

Wildasin, D. E. (1990). Budgetary pressures in the EEC: A fiscal federalism perspective. American Economic Review, 80(2), 69-74.

Ye, F., \& Wang, W. (2013). Determinants of Land Finance in China: A Study Based on Provincial-level Panel Data Australian Journal of Public Administration, 72(3), 293-303.

\section{Copyrights}

Copyright for this article is retained by the author(s), with first publication rights granted to the journal.

This is an open-access article distributed under the terms and conditions of the Creative Commons Attribution license (http://creativecommons.org/licenses/by/3.0/). 